\title{
Effects of Propoxur on the Reproductive System of Male Rats
}

\author{
Ferdinand Ngoula, Pierre Watchob, Tepi Serges Bousekob, Augustave Kenfack, Joseph Tchoumboué, Pierre \\ Kamtchouing
}

\begin{abstract}
The reproductive toxicity of propoxur (2-isopropoxy-phenyl-N-methylcarbamate), a carbamate pesticide, was investigated in adult male Wistar rats exposed to $0,1.73,2.6$, and $5.2 \mathrm{mg} / \mathrm{kg}$ body weight/day for 90 successive days. Results obtained from this study showed a significant $(\mathrm{p}<0.05)$ concentration-dependent increase in food consumption, relative weights of testis, epididymis and kidneys with maximum effects observed at the highest dose of propoxur $(5.2 \mathrm{mg} / \mathrm{kg})$ compared to the control. On the contrary, there was a significant $(\mathrm{p}<0.05)$ decrease in the body weight gain, sperm density, serum and intratesticular total cholesterol concentrations, and intratesticular total proteins in rats treated with propoxur at the dose of $5.2 \mathrm{mg} / \mathrm{kg}$ body weight. Propoxur had no significant effect on gestation, fertility and parturition indices, average birth weight, litter size and pups sex ratio of untreated female rats mated with treated males rats. These results suggested that propoxur increased food consumption, relative weight of reproductive and detoxication organs, decreased body weight gain and sperm density per gram of cauda epididymis without affecting the reproductive performances. (Rev Afr Santé Reprod 2007; 11[1]:125-132).
\end{abstract}

\section{RÉSUMÉ}

Effets du propoxur sur le système de reproduction des rats mâles La toxicité de reproduction du propoxur (2isopropoxy) (2-isopropoxyphenyl - N - méthylcarbamate), un pesticide carbamate a été étudié chez les rats adultes de souche Wistar exposés à un poids corporel de $0,1,73 ; 2,6$ et 5,2 $\mathrm{mg} / \mathrm{kg}$ de poids corporel par jour pendant 90 jours successifs. Les résultats obtenus à partir de cette étude ont montré une croissance significative dans la consommation de la $(\mathrm{p}<0,05)$ nourriture qui dépende de la concentration, des poids relatifs de testieules, l'épididyme et des reins. Les effets maximums ont été remarqués au point de la dose la plus forte du propoxur (5, $2 \mathrm{mg} / \mathrm{kg})$ par rapport au contrôle. Par contre, il y a eu une baisse significative $(\mathrm{p}<0,5)$ du gain de poids corporel de, la densité du sperme, du serum et des concentrations du cholesterol total intratesticulaire et les protein total intratesticulaire chez les rats qui ont été traités à l'aide du propoxur à la dose de $5,2 \mathrm{mg} / \mathrm{kg}$ de poids corporel par rapport au contrôle. Le propoxur n'a pas eu un effet significatif $(p>0,05)$ sur la gestation, les indices de la fécondité et de la parturition, le poids de naissance moyen, la taille de la portée et le sex-ratio des rats femelles qui n'ont pas été traités ont croisées avec les rats mâles traités. Ces résultats ont suggéré que propoxur a augmenté la consommation de la nourriture, le poids relatif des organes de reproduction et de détoxication, diminue le gain de poids corporel et de la concentration du sperme par gramme de queue de l'épididyme sans que cela affecte des performances de la reproduction. (Rev Afr Santé Reprod 2007; 11[1]:125-132).

KEY WORDs: propoxur, fertility, male rats

${ }^{a}$ University of Dschang, Faculty of Agronomy and Agricultural Sciences, Department of Animal Productions . PO. Box: 222 Dschang-Cameroon ${ }^{b}$ University of Dschang, Faculty of Science, Department of Animal Biology, PO. Box: 67 Dschang-Cameroon 'University of Yaoundé I, Faculty of Science, Department of Animal Biology and physiology, PO. Box: 812 Yaoundé-Cameroon.

Corresponding author: Ferdinand Ngoula, University of Dschang, Faculty of Agronomy and Agricultural Sciences, Department of Animal Productions, Laboratory of Animal physiology. P.O Box: 188 Dschang-Cameroon. Telephone: (237) 51254 43; E-mail: fngoula@yahoo.fr or fngoula2004@yahoo.fr 


\section{Introduction}

Propoxur (2-isopropoxy-phenyl-N-methylcarbamate) is a non-systemic insecticide which was introduced in 1959 (Hayes and Laws, 1990). It is used against mosquitoes in outdoor areas, against flies in agricultural settings, against fleas and ticks on pets, as an acaricide, on lawns and turf for ants, on flowering plants, and in private dwellings and public buildings. It is also used as a molluscicide. It is effective against cockroaches, aphids and leafhoppers (EXTOXNET, 1996). Propoxur is one of the chemicals that have, to a large extent, replaced DDT in the control of black flies and mosquitoes (Mc Ewen and Stephenson, 1979). Like all N-methyl carbamates and organophosphorous insecticides, propoxur is believed to act by inhibiting acetylcholinesterase activity (Baron, 1991; Timbrell, 2000). This results in accumulation of acetylcholine in the synapse, which in turn can stimulate cholinergic receptors producing both nicotinic and muscarinic effects in the organism, such as muscle contractions and secretion in many glands (Taylor, 1990).

Because of its toxicity and widespread use, the possibility that propoxur can affect humans and wildlife in their natural habitats is of great concern. There is abundant information about the neurotoxic effects of propoxur, but less is known about its impact on reproduction. US Environmental Protection Agency (1999) reported decreased numbers of pups, and depressed fetal weight in rats orally exposed to propoxur. Other studies on rats showed the reduction of the weight of pups born from mothers treated with propoxur at the dose of 5 $\mathrm{mg} / \mathrm{kg} /$ day (Baron, 1991). In addition, Löser (1968) reported the reduction of pup weight, parental weight and smaller litter size in female rats fed propoxur in the diet at level of $6000 \mathrm{ppm}$.

The toxicity of propoxur on female reproductive system is known, but the literature available on its effect on male reproductive system is scanty. The present paper attempts to report the toxic effects of propoxur on some reproductive parameters in male rats.

\section{Material and Methods}

\section{Animals}

Healthy adult male Wistar rats weighing 250 $300 \mathrm{~g}$ were used in this study. Animals were housed in wire cages $(50 \mathrm{~cm}$ long X $25 \mathrm{~cm}$ wide $\mathrm{X} 25 \mathrm{~cm}$ high), six per cage in a centralized animal care facility maintained at 22 to $25{ }^{\circ} \mathrm{C}$ with a relative humidity of $76 \pm 5 \%$. Animals were kept in a $12 \mathrm{~h}$ light-dark cycle and provided water and laboratory diet ad libitum.

\section{Chemical and preparation}

Undene (BAYER AG, Germany) is a carbamate pesticide whose active principle is propoxur concentrated at $75 \%$. Undene is a white crystalline powder with a faint characteristic odour and a melting point of $86-91.5^{\circ} \mathrm{C}$. it is soluble in polar organic solvents, but only slightly soluble in non polar-organic solvents. It is unstable in highly alkaline media with a half-life of 40 minutes at pH 10 (W.H.O. and F.A.O., 1976). The working solution $(5 \mathrm{mg} / \mathrm{mL})$ was extemporary prepared by dissolving $1 \mathrm{~g}$ of Undene powder in $200 \mathrm{~mL}$ of distilled water.

\section{Experimental design}

Four groups of 6 male rats each were administered propoxur at a dose rate of 0 (water, control), 1.73, 2.6 and $5.2 \mathrm{mg} / \mathrm{kg}$ body weight per day orally by gastric intubation in a dose volume of $10 \mathrm{~mL} / \mathrm{kg}$. Volumes were adjusted weekly for body weight. The doses used in our study corresponded respectively to $1 / 30,1 / 20$ and $1 / 10$ of oral $\mathrm{LD}_{50}$ value $(52 \mathrm{mg} / \mathrm{kg}$ ) obtained in mice (personal communication). All animals were treated for 90 days during which their body weight and food intake were measured at 2 days interval.

African Journal of Reproductive Health Vol. 11 No.1 April 2007 


\section{Fertility test}

On the $80^{\text {th }}$ day of drug administration, each male was mated with 2 females of proven fertility. Every morning, the vaginal smear was examined for the presence of sperms. The presence of spermatozoa in the vaginal smear was considered as day 1 of pregnancy. The female rat was then caged separately up to the supposed day of delivery $\left(22^{\text {nd }}-24^{\text {th }}\right.$ day). Immediately after delivery, pups were examined for litter size, litter weight, sex and viability. Various reproductive indices including fertility index (number of pregnant animals / number of females mated) X 100 , gestation index (number of pups born alive / number of total pups born) X 100, and parturition index, (number of females delivered / number of pregnant animals) X 100 were calculated according to the methods of Kennedv et al (1973) and Wernik et al (1975).

\section{Serum and organ collections}

One day after the last drug administration $\left(91^{\text {th }}\right.$ day), blood was collected by cardiac puncture from each rat under ether anaesthesia. Serum was prepared and stored at $-20^{\circ} \mathrm{C}$ prior to analysis. After blood collection, rats were killed with an overdose of ether. Organs like testes, epididymis, ventral prostate, vas deferens, seminal vesicles, liver and kidneys were carefully removed, freed of adipose tissue, blotted dried and weighed separately. The left testis was then homogenised in a known volume of cold distilled water and aliquots were kept at $-20^{\circ} \mathrm{C}$ prior to biochemical analyses.

\section{Sperm density and motility}

Immediately after sacrifice, the right cauda epididymis of each rat was minced and thoroughly mixed in $10 \mathrm{~mL}$ of warm $\left(36{ }^{\circ} \mathrm{C}\right)$ $0.9 \% \mathrm{NaCl}$ solution for motility evaluation. 20 $\mu \mathrm{L}$ of this mixture was observed under a light microscope (ZEISS, $40 \mathrm{X}$ ). Motile and nonmotile sperms were counted in 8 fields and the percentage of motile spermatozoa determined using the following formula:

\section{Percentage of mobile spermatozoa $=$ (Number of mobile spermatozoa / Total number of counted spermatozoa) $X 100$}

For sperm density, a twenty-fold dilution was made by mixing the sperm suspension with Marcano solution and the mixture was shacked gently. Sperm were counted on a Bürker cell.

\section{Biochemical analysis}

Total protein contents of serum and testes were determined by the methods of Biuret (Gornal et al, 1949) and Bradford (1976), respectively.

The level of total cholesterol in serum and testes was determined using the commercial kit from Human Gesellschaft für Biochemica und Diagnostica mbH (Wiesbaden-Germany).

\section{Statistical analysis}

Statistical analyses were performed with the aid of SPSS for Windows software programme (release 10.1). Values are presented as mean \pm standard deviation ( \pm SD). ANOVA was performed for comparison with post-hoc Duncan test. A p value of $<0.05$ was considered statistically significant.

\section{Results}

\section{Food intake}

The effects of propoxur on food consumption are summarized in Table 1. During the first month of treatment (first to thirtieth day), the food consumption remained unchanged $(p>0.05)$ between groups. From thirty-first to sixtieth day of treatment, the food intake recorded in rats receiving $2.6 \mathrm{mg} / \mathrm{kg}$ body weight of propoxur was significantly $(\mathrm{p}<0.05)$ higher as compared to the controls and $1.73 \mathrm{mg} / \mathrm{kg}$ rats. On the other hand, from sixtieth to ninetieth day of treatment, food consumption exhibited a significant $(p<0.05)$ 
Table 1: Effects of propoxur on food consumption ( $\mathrm{g} / \mathrm{kg} /$ day)

\begin{tabular}{|c|c|c|c|c|}
\hline \multirow{2}{*}{$\begin{array}{l}\text { Treatment periods } \\
\text { (days) }\end{array}$} & \multicolumn{4}{|c|}{ Propoxur (mg/kg/body weigt) } \\
\hline & $\begin{array}{c}0 \text { (control) } \\
(\mathrm{n}=6)\end{array}$ & $\begin{array}{c}1.73 \\
(n=6)\end{array}$ & $\begin{array}{c}2.6 \\
(n=6)\end{array}$ & $\begin{array}{c}5.2 \\
(n=6)\end{array}$ \\
\hline $1-30^{\text {th }}$ & $114,02 \pm 29.86^{a}$ & $106,95 \pm 36,46^{a}$ & $94,89 \pm 27,46^{a}$ & $117,02 \pm 26,14^{a}$ \\
\hline $31-60^{\text {th }}$ & $83,35 \pm 17,96^{a}$ & $81,49 \pm 15,78^{a}$ & $103,01 \pm 29,98^{\mathrm{b}}$ & $97,96 \pm 20,77^{\mathrm{ab}}$ \\
\hline $61-90^{\text {th }}$ & $75,44 \pm 24,46^{a}$ & $96,30 \pm 19,16^{\mathrm{b}}$ & $77,28 \pm 19,30^{b}$ & $106,65 \pm 15,28^{b}$ \\
\hline $1-90^{\text {th }}$ & $90.55 \pm 29.25^{\mathrm{a}}$ & $94.93 \pm 26.80^{\mathrm{a}}$ & $96.85 \pm 21.70^{\mathrm{ab}}$ & $107.20 \pm 25.95^{b}$ \\
\hline
\end{tabular}

$a, b$ : values with the same letter in a row are not significantly different $(P>0.05)$.

All values $=$ mean $\pm S D$

$\mathrm{n}=$ number of rats

increase in rats which received propoxur as compared to control.

\section{Body weight gain and relative weight of} organs

Results of the effects of propoxur on body weight gain and relative organ weights are given in Table 2. It is shown that body weight gain was significantly $(p<0.05)$ decreased in all propoxur treated animals whereas the relative organ weight of the testes, epididymis and kidneys was significantly $(\mathrm{p}<0.05)$ increased in rats treated with propoxur at the doses of 2.6 and $5.2 \mathrm{mg} / \mathrm{kg}$ body weight as compared to the control. The ventral prostate, liver, seminal vesicles and vas deferens remained unchanged in the study.

\section{Sperm density and motility}

The sperm density per gram of cauda epididymis significantly $(p<0.05)$ decreased in rats treated with the highest dose of propoxur $(5.2 \mathrm{mg} / \mathrm{kg}$ body weight) (Table 3). At all doses, sperm density per cauda epididymis and sperm motility of propoxur treated rats was found to be within the normal range as compared with control animals (Table 3).

\section{Biochemical parameters}

Serum and intratesticular cholesterol levels were significantly $(\mathrm{p}<0.05)$ decreased in rats that received propoxur at doses of 1.73 and $2.6 \mathrm{mg} /$ $\mathrm{kg}$ as compared to controls. (Table 3). Total protein contents of testes was significantly $(p<0.05)$ decreased in rats treated with propoxur as compared to untreated animals whereas total protein content of serum was significantly $(\mathrm{p}<0.05)$ increased (Table 3$)$.

\section{Fertility}

Treatment of rats for 90 days with propoxur produced no significant $(\mathrm{p}>0.05)$ changes in the various reproductive indices (fertility, gestation and parturition indices) as well as on the pups sex ratio when compared to control animals (Table 3).

\section{Discussion}

The present study was carried out in order to determine the effects of Undene on the reproductive system of male rat. Undene is a carbamate pesticide whose active principle is propoxur (2-isopropoxy-phenyl-N-methylcarbamate), a compound well known for its neurotoxic effects (Baron, 1991; Van Hamme and Wattiez, 1999). From the results obtained, it appears that during the last thirty days of treatment, the food consumption significantly increased in rats treated with propoxur as compared to control. This hyperphagia may be related to the effects of this pesticide on the central structures involved in the control of food intake. Psychoyos (1983), Fox

African Journal of Reproductive Health Vol. 11 No.1 April 2007 
Table 2: Effects of propoxur on body weight and relative organ weight

\begin{tabular}{|c|c|c|c|c|}
\hline \multirow[t]{2}{*}{ Parameters } & \multicolumn{4}{|c|}{ Propoxur (mg/kg body weight) } \\
\hline & 0 (control) & $\begin{array}{c}1.73 \\
(n=6)\end{array}$ & $\begin{array}{c}2.6 \\
(n=6)\end{array}$ & $\begin{array}{c}5.2 \\
(\mathrm{n}=6)\end{array}$ \\
\hline Body weight gain (\%) & $72.88 \pm 28.00^{a}$ & $62.88 \pm 19.19^{\mathrm{ab}}$ & $37.11 \pm 17.11^{\mathrm{c}}$ & $46.52 \pm 20.57 \mathrm{bc}$ \\
\hline \multicolumn{5}{|l|}{$\begin{array}{l}\text { Relative organ weight } \\
\text { ( } \mathrm{g} / 100 \mathrm{~g} \text { of body weight) }\end{array}$} \\
\hline Testes & $0.85 \pm 0.16^{a}$ & $0.96 \pm 0.12 \mathrm{ab}$ & $1.13 \pm 0.15^{\mathrm{b}}$ & $1.09 \pm 0.11^{\mathrm{b}}$ \\
\hline Epididymis & $0.26 \pm 0.06^{\mathrm{a}}$ & $0.29 \pm 0.04 \mathrm{ab}$ & $0.35 \pm 0.02^{\mathrm{c}}$ & $0.33 \pm 0.04 \mathrm{bc}$ \\
\hline Vas deferens & $0.06 \pm 0.01^{\mathrm{a}}$ & $0.06 \pm 0.01^{\mathrm{a}}$ & $0.07 \pm 0.01^{\text {a }}$ & $0.07 \mathrm{~h} \pm 0.01^{\mathrm{a}}$ \\
\hline Ventral prostate & $0.10 \pm 0.02^{a}$ & $0.14 \pm 0.03^{\text {a }}$ & $0.12 \pm 0.03^{\text {a }}$ & $0.14 \pm 0.04^{\mathrm{a}}$ \\
\hline Seminal vesicles & $0.42 \pm 0.14$ ab & $0.35 \pm 0.04^{\mathrm{a}}$ & $0.46 \pm 0.10^{\mathrm{ab}}$ & $0.50 \pm 0.10^{\mathrm{b}}$ \\
\hline Liver & $2.92 \pm 0.33^{\mathrm{a}}$ & $2.94 \pm 0.24^{\mathrm{a}}$ & $3.31 \pm 0.37^{\text {a }}$ & $3.06 \pm 0.33^{\mathrm{a}}$ \\
\hline Kidneys & $0.53 \pm 0.60^{\text {a }}$ & $0.57 \pm 0.02^{\mathrm{ab}}$ & $0.61 \pm 0.80^{\mathrm{b}}$ & $0.62 \pm 0.60^{\mathrm{b}}$ \\
\hline
\end{tabular}

Table 3: Effects of propoxur on sperm characteristics, biochemical and fertility Parameters

\begin{tabular}{|c|c|c|c|c|}
\hline \multirow[b]{2}{*}{ Parameters } & \multicolumn{4}{|c|}{ Propoxur (mg/kg of body weight) } \\
\hline & $\begin{array}{l}0 \text { (control) } \\
(n=6)\end{array}$ & $\begin{array}{l}1.73 \\
(n=6)\end{array}$ & $\begin{array}{c}2.6 \\
(n=6)\end{array}$ & $\begin{array}{c}5.2 \\
(n=6)\end{array}$ \\
\hline \multicolumn{5}{|l|}{ Sperm characteristics } \\
\hline \multicolumn{5}{|l|}{ Sperm density $\left(\mathrm{x} 10^{6}\right)$} \\
\hline Per cauda epididymis & $137.50 \pm 15.65^{\mathrm{a}}$ & $143.61 \pm 29.54^{\mathrm{a}}$ & $141.70 \pm 9.80^{\mathrm{a}}$ & $145.702 \pm 5.69^{a}$ \\
\hline Per $g$ of cauda epididymis & $869.75 \pm 75.36^{\mathrm{a}}$ & $800.32 \pm 38.21^{\mathrm{ab}}$ & $779.53 \pm 132.07^{\mathrm{ab}}$ & $774,70 \pm 111,13^{\mathrm{b}}$ \\
\hline Motility (\%) & $87.73 \pm 6.98^{\mathrm{a}}$ & $90.90 \pm 4.25^{\mathrm{a}}$ & $86.01 \pm 7.23^{\mathrm{a}}$ & $91.80 \pm 3.92^{\mathrm{a}}$ \\
\hline \multicolumn{5}{|l|}{ Biochemical parameters } \\
\hline Serum proteins $(\mathrm{mg} / \mathrm{ml})$ & $2.01 \pm 0.20^{\mathrm{a}}$ & $2.20 \pm 0.09^{\mathrm{b}}$ & $2.26 \pm 0.12^{\mathrm{b}}$ & $2.23 \pm 0.19^{\mathrm{b}}$ \\
\hline Testes proteins $(\mu \mathrm{g} / \mathrm{g})$ & $61.24 \pm 13.58^{\mathrm{a}}$ & $30.74 \pm 5.46^{\mathrm{b}}$ & $44.63 \pm 8.59^{c}$ & $45.41 \pm 556^{c}$ \\
\hline Serum cholesterol $(\mathrm{mg} / \mathrm{ml})$ & $1.92 \pm 0.27^{\mathrm{a}}$ & $1.37 \pm 0.20^{\mathrm{b}}$ & $1.28 \pm 0.36^{\mathrm{b}}$ & $1.79 \pm 0.36^{\mathrm{a}}$ \\
\hline Testis cholesterol (mg/g) & $1.39 \pm 0.09^{\mathrm{a}}$ & $0.92 \pm 0.23^{\mathrm{b}}$ & $0.77 \pm 0.28^{\mathrm{b}}$ & $1.12 \pm 0.24^{\mathrm{a}}$ \\
\hline \multicolumn{5}{|l|}{ Fertility parameters } \\
\hline Fertility index $(\%)$ & $70.00 \pm 27.38^{\mathrm{a}}$ & $80.00 \pm 27.38^{\mathrm{ab}}$ & $62.50 \pm 25.00^{\mathrm{a}}$ & $75.00 \pm 27.38^{\mathrm{a}}$ \\
\hline Parturition index $(\%)$ & $100.00 \pm 0.00^{\mathrm{a}}$ & $100.00 \pm 0.00^{\mathrm{a}}$ & $100.00 \pm 0.00^{\mathrm{a}}$ & $100.00 \pm 0.00^{\mathrm{b}}$ \\
\hline Gestation index $(\%)$ & $96.92 \pm 6.28^{\mathrm{a}}$ & $100.00 \pm 0.00^{\mathrm{a}}$ & $92.89 \pm 8.44^{\mathrm{a}}$ & $100.00 \pm 0.00^{\mathrm{a}}$ \\
\hline Average birth weight $(\mathrm{g})$ & $4.35 \pm 0.8^{\mathrm{a}}$ & $4.09 \pm 0.6^{\mathrm{a}}$ & $4.12 \pm 0.65^{a}$ & $3.18 \pm 0.54^{a}$ \\
\hline Average litter size & $7.20 \pm 1.09^{\mathrm{a}}$ & $6.60 \pm 1.34^{a}$ & $7.12 \pm 1.03^{\mathrm{a}}$ & $6.08 \pm 0.80^{a}$ \\
\hline Male pups sex-ratio & $48.617 \pm 6.21^{\mathrm{a}}$ & $49.16 \pm 20.33^{\text {a }}$ & $47.35 \pm 9.48^{\mathrm{a}}$ & $49.75 \pm 17.26^{\mathrm{a}}$ \\
\hline
\end{tabular}

$a, b, c:$ value with the same letter in a row are not significantly different $(P>0.05)$.

All values $=$ mean $\pm S D$

$\mathrm{n}=$ number of rats 
(1999) and Ganong (2001) have linked hyperphagia with stimulation of the ventromedian nucleus of the hypothalamus.

The decrease observed in the body weight gain of the treated rats denotes intracellular deficiency in glucose and tissue damage; this statement may be supported by the decrease in intratesticular protein content and the increase in serum total proteins. Proteins are the must important and abundant macromolecules playing a vital role in the architecture and physiology of the cell and in cellular metabolism (Mommsen and Walsh, 1992). Under stress conditions, the dietary proteins consumed by rats are not stored in the body tissue (Palanichamy, 1990) and hence the treated rats met their extra energy requirements from body proteins which are mobilized to produce glucose, the instant energy of which is made available by the process of gluconeogenesis (Vasanthi et al, 1990); thus, the decreased protein content of testes may be attributed to the tissue injuries and consequent impairment in protein synthesis machinery. Whereas total protein contents of the serum are increased. It has been reported that enhancement in the level of serum proteins is indicative of tissue injury (Emerson et al, 1993; Gatsing et al, 2005). The decrease in body weight gain can also be explained by the fact that the energy coming from feed consumed was mostly used in the detoxication mechanism i.e. metabolism, degradation and elimination of pesticide out of the organism.

The increase in the relative weight of testes, epididymis, ventral prostate, seminal vesicles, liver and kidneys observed after propoxur administration could be attributed to the eodematous effects of propoxur. Blanchet et al (1991) have demonstrated that organophosphorous insecticides possess neurotoxic effects evidenced by accumulation of water in a variety of tissues. The neurotoxic effects of propoxur may then account for the above oedematous hypothesis.

It is well established that carbamate and organophosphorous pesticides reduce acetylcho- linesterase activity and block nerve impulses (Hayes and Laws, 1990; Short and Colborn, 1999; Gwynne, 2000). This effect may alter the release of pituitary hormones, namely FSH and LH, leading to the reduction of sperm production in the testes. This hypothesis could explain the significant decrease in sperm density per gram of tissue recorded in rats treated with the highest dose of propoxur ( $5.2 \mathrm{mg} / \mathrm{kg}$ body weight). The decrease observed in the serum and intratesticular total cholesterol contents did not support this statement since the use of cholesterol in steroidogenic processes depends on the availability of LH (Dadoune and Demoulin, 2001). It could then be proposed that the significant reduction in cholesterol contents could be linked to some disturbances in the metabolism of this substance.

Gestation, fertility and parturition indices, average birth weight, litter size and pups sex ratio of untreated female rats mated with treated males was not affected in the study. Thus, the decrease of sperm density per gram of cauda epididymis was not enough to reduce fertility. But as mentioned by kimmel et al. (1995), clear differences exist between the reproductive system of laboratory animals and that of humans. As noted, laboratory animal species are considerably more efficient at sperm production than is the human male. Thus, a lowering of sperm count that does not have a measurable effect on the fertility of laboratory animal species being tested may still be significant with respect to human fertility.

In conclusion, propoxur increased food consumption, relative weights of testes, epididymis, ventral prostate, seminal vesicles, liver and kidneys; decreased body weight gain and sperm density per gram of cauda epididymis without affecting the reproductive performances.

\section{Acknowledgments}

This work was supported, in part, by a grant from Cameroon ministry of higher education.

African Journal of Reproductive Health Vol. 11 No.1 April 2007 


\section{REFERENCES}

1. Baron, R. L. Carbamate insecticides. In Handbook of Pesticide Toxicology. Hayes, W. J., Jr. and Laws, E. R., Jr., Eds. Academic Press, New York, NY, 1991: 3-6.

2. EXTOXNET. PIP-Propoxur. USDA/Extension Service/National Agricultural Pesticide Impact Assessment Program, 1996; 6p.

3. Mc Ewen, F L and Stephenson GR. The Use and Significance of Pesticides in the Environment. John Wiley and Sons, Inc., New York, NY, 1979, 3-41.

4. Baron R L. Carbamate insecticides. In: Handbook of Pesticide Toxicology. Hayes W J Jr and Laws E R Jr (Eds). Academic Press, New York, NY, 1991, pp 3-6.

5. Timbrell J. Principles of Biochemical Toxicology. $3^{\text {rd }}$ ed., Taylor \& Francis, London, 2000. 138-184.

6. Taylor P. Anticholinesterase agents. In: Goodman Gilman A, Rall TW, Nies AS, Taylor P. (Eds). The pharmacological Basis of therapeutics, Pergamon Press Inc New-York, 1990, 131 - 147.

7. U.S. Environmental Protection Agency. Integrated Risk Information system (IRIS) on Baygon. National Center for Environmental Assessment, Office of Research and Development, Washington, DC, 1999; 6p.

8. Löser, E BAY 39 007/Generationsversuche an Ratten. Unpublished report submitted by Bayer AG, 1968; 23p.

9. WHO/FAO. 1973 Evaluations of some pesticide residues in food, W.H.O. Pesticides Residues Series, No. 3. World Health Organization, Geneva, 1974; 49p.

10. Kennedv, GL. Jr, John, P, Frawley, J, Calandra, JC Multigeneration reproductive effects of three pesticides in rats. Toxicol. Appl. Pharmacol., 1973; 25: 589-596.

11. Wernik T, Lamman BM, Franx JL. Chronic toxicity Teratologic and reproduction studies with hair dyes. Toxicol appl pharmacol, 1975; 32: 450-60.

12. Gornal AG, Bardwil GS, David MM. Determination of serum proteins by mean of Biuret reactions. Biochemistry, 1949; 177: 751-766.

13. Bradford MN. A rapid and sensitive method for the quantification of microgram quantity of protein-dye binding. Analytical Biochemistry, 1976; 72: 248-254.

14. Van Hamme ML and Wttiez C. Pesticides a usage domestique. Pesticide Action Network Belgium, $1999 ; 47 \mathrm{p}$

15. Blanchet $G$, Carpentier P, Lallement G. Vulnérabilité du système nerveux central vis-à-vis des neurotoxiques organophosphorés. Méd. Armées, 1991; 19: 403-407.

16. Saïssa JM and Rüttimann M. Intoxication par les organophosphorés. Médecine d'urgence, Elsevier, Paris, et SFAR, 1999, 103-120.

17. Psychoyos A. La reproduction. In : Meyer P, ed. Physiologie Humaine. Paris: Flammarion Médecine-Sciences; 1983: 471-493.

18. Fox SI. Human Physiology. Sixth edition, Boston: Mc. Graw-Hill; 1999: 612-614.

19. Ganong WF. Physiologie médicale. Masson, Paris, 2001, 408-411.

20. Mommsen TP and Walsh PJ. Biochemical and environmental perspectives on nitrogen metabolism in fishes, Experientia, 1992; 48: 583-593.

21. Palanichamy B.S. Impact of agricultural (ammonium chloride) fertilizer on physiology and biochemistry of fresh water teleost fish, Oreochromis mossambicus, J. Ecobiol., 1990; 2: 97-106.

22. Vasanthi R, Baskaran P and Palanichamy S. Influence of carbofuran on growth and protein conversion efficiency in some fresh water fishes. J Ecobiol., 1990; 2: 85-88.

23. Emerson FS, Shadara AC and Devi PU. Toxic effects of Crude extract of Plumbago rosea (Rokta chitraka). J. Ethnopharm., 1993; 38: 79-84.

24. Gatsing D, Aliyu R, Kuate JR, Garba IH, Jaryum $\mathrm{KH}$, Tedongmo N, Tchouanguep F and Adoga GI. Toxicological evaluation of the aqueous extract of Allium sativum bulbs on laboratory mice and rat, Cameroon Journal of Experimental Biology, 2005; 1:39-45.

25. Short P, Colborn T. Pesticides use in the U.S. and polity implications. Toxicology and Industrial Health, 1999; 15: 240-275.

26. Gwynne L. Mixed messages: Pesticides that confuse hormones. Pesticide Action Network (P.A.N.) U.K. Briefing paper, 2000, 6 p. 
27. Dadoune JP, Demoulin A. Structure et fonction du testicule. In: Thibault C and Levasseur M C (Eds). La reproduction chez les mammifères et l'Homme. Nouvelle édition, Ellipses éditions, Paris, 2001; 256-289.
28. Kimmel GL, Clegg ED, and Crisp TM. Reproductive toxicity testing: A risk assessment perspective. In: Witorsch RJ (ed.). Reproductive toxicology, second edition, Raven Press, Ltd., New York, 1995; 75-98. 